\title{
Binol Based Chirality Conversion Reagents for Underivatized Amino Acids
}

\author{
Krishnaswamy Velmurugan1, Lijun Tang2, Raju Nandhakumar1 \\ ${ }^{1}$ Synthesis and Chemosensor Lab, Department of Chemistry, Karunya University, Coimbatore, India \\ ${ }^{2}$ College of Chemistry and Chemical Engineering, Liaoning Key Laboratory for the Synthesis and Application of \\ Functional Compounds, Bohai University, Jinzhou, China \\ Email: lijuntang@tom.com, nandhakumar@karunya.edu
}

Received 13 January 2014; revised 17 February 2014; accepted 25 February 2014

Copyright (C) 2014 by authors and Scientific Research Publishing Inc.

This work is licensed under the Creative Commons Attribution International License (CC BY). http://creativecommons.org/licenses/by/4.0/

(c) (i) Open Access

\begin{abstract}
Four binol based pyrrole carboxamide chiral receptors has been synthesized and effectively used as a Chirality Conversion Reagent (CCR) for underivatized amino acids. Three points of interactions take place for the conversion process. They are the reversible imine formation, the internal resonance assisted Hydrogen Bonding (RAHB) and the additional hydrogen bonds between the amino acids and the heterocylic moiety of the pendant groups. The conversion efficiency of all the receptors was found to be comparable with those of the receptors reported earlier.
\end{abstract}

\section{Keywords}

Binol Based Receptors; Chiral Recognition; Amino Acids; Amino Alcohols; Chiral Inversion; ${ }^{1}$ H-NMR

\section{Introduction}

Enantiomerically pure amino acids emerged as an interesting and rewarding synthetic target during the past decade, because of their increasing industrial importance as chiral building blocks in ligand design and total synthesis. In particular, preparation of D-amino acids has attracted considerable attention not only because of their importance in the synthesis of pharmaceuticals, food ingredients, and drug intermediates but also due to the lack of natural resources and preparation requires high cost [1]-[8]. Even though a wealth of organic, biological, polymeric and metal based amino acid receptors have been developed during the past years [9]-[15], there has been a rare example of a chirality conversion reagent(CCR) for a wide range of underivatized amino acids [16].

Earlier, we showed several binol based receptors as able CCR's which convert amino acids [17]-[19] and peptides [20] [21] from L-form to D-form by the reversible imine formation [22] [23]. Multiple hydrogen bonding 
dur- ing the imine formation along with internal Resonance-Assisted H-bonds (RAHBs) play important roles in de- termining the stereoselective ratio (D/L) during the Chirality Conversion (CC). Recently, we reported pyrrole- 2-carboxamide [24] based binol receptors and their analogues $\mathbf{1}$ - $\mathbf{4}$ for chiral discrimination and enantioselective recognition of chiral amino alcohols (Scheme 1). Herein, we report the pyrrole-2-carboxamide based binol re- ceptors for enantioselective recognition and also as potential CCR's for chiral amino acids.

\section{Experimental}

\subsection{General}

Imidazole-2-carboxylic acid and benzimidazole carboxylic acid were prepared according to the literature procedures [24]. All other chemicals were commercially available and used without further purifications. The solvents for dry reactions were dried with appropriate desiccants and distilled prior to use. NMR spectra were recorded on a BrukerAM 250 spectrometer in $\mathrm{CDCl}_{3}$ solution containing tetramethylsilane as internal standard. Melting points were measured with Electrothermal IA 9000 digital melting point apparatus and are uncorrected. HRMS spectra were obtained on FAB mode. EA was determined using vario EL Elemental Analyser. For column chromatography, silica gel of 230 - 400 mesh was used.

\section{2. (S)-3-Hydroxymethyl-2-Methoxymethoxy-2'-(3-(1H-Pyrrole-2-Carboxamido) -Benzyl)-1,10-Binaphthalene (6)}

A mixture of the 2-pyrrole carboxylic acid (0.49 g, $4.4 \mathrm{mmol}$ ), PyBOP (2.3 g, $4.4 \mathrm{mmol})$, and N-methyl morpholine (NMP, $2 \mathrm{ml}$ ) in DMF (40 ml) was stirred at room temperature for $15 \mathrm{~min}$. Amine 5 (2.0 g, $3.7 \mathrm{mmol}$ ) was added and the mixture was stirred over night. The mixture was hydrolyzed with water, extracted with ethyl acetate, and silica gel column chromatography (EA/Hexane, 1:1) afforded 6. Isolated yield: $81 \%\left(\mathrm{mp} 105^{\circ} \mathrm{C}\right) .{ }^{1} \mathrm{H}$ NMR $\left(\mathrm{CDCl}_{3}, 250 \mathrm{MHz}\right): \delta(\mathrm{ppm})=9.77($ br s, $1 \mathrm{H}), 8.20(\mathrm{~s}, 1 \mathrm{H}), 8.04-7.84(\mathrm{~m}, 5 \mathrm{H}), 7.52-7.00(\mathrm{~m}, 7 \mathrm{H}), 6.74$ - 6.38 (m, 5H), 6.12 (s, $1 \mathrm{H}), 5.00$ - 4.90 (m, 3H), 4.66 - 4.51 (m, 4H), 3.47 (s, 3H); ${ }^{13} \mathrm{C}$ NMR $\left(\mathrm{CDCl}_{3}, 63 \mathrm{MHz}\right)$ : $\delta(\mathrm{ppm})=162.7,158.2,157.2,148.6,141.4,136.1,132.5,128.9,128.3,128.1,127.6,127.4,125.7,124.1,123.3$, 122.8, 122.3, 119.4, 119.3, 111.7, 95.7, 71.2, 64.9, 55.6. Anal. Calcd for $\mathrm{C}_{35} \mathrm{H}_{30} \mathrm{~N}_{2} \mathrm{O}_{5}$ : C, 75.25; H, 5.41; N, 5.01. Found: C, 75.34; H, 5.53; N, 4.92.

\section{3. (S)-3-Hydroxymethyl-2-Methoxymethoxy-2'-(3-(1H-Indole-2-Carboxamido)-Benzyl) -1,10-Binaphthalene (7)}

It was prepared similar to 6, but with indole-2-carboxylic acid. Isolated yield: $86 \%$ (mp $158^{\circ} \mathrm{C}$ ). ${ }^{1} \mathrm{H}$ NMR $\left(\mathrm{CDCl}_{3}, 250 \mathrm{MHz}\right): \delta(\mathrm{ppm})=10.55(\mathrm{~s}, 1 \mathrm{H}), 9.04(\mathrm{~s}, 1 \mathrm{H}), 7.95-7.77(\mathrm{~m}, 8 \mathrm{H}), 7.47-7.07(\mathrm{~m}, 11 \mathrm{H}), 6.80(\mathrm{~d}$, 1H), 5.18 - 5.04 (dd, 2H), 4.96 (d, 2H), 4.60 (q, 2H), 4.35 (br s, 1H), 3.08 (s, 3H); ${ }^{13} \mathrm{C} \mathrm{NMR}\left(\mathrm{CDCl}_{3}, 63 \mathrm{MHz}\right): \delta$ $(\mathrm{ppm})=160.5,57.9,156.7,144.3,141.5,138.5,136.1,134.7,131.2,129.9,129.8,129.2,128.7,128.3,128.0$, 127.4, 126.0, 125.7, 124.1, 123.9, 122.8, 122.2, 120.1, 119.0, 115.6, 111.1, 97.6, 70.5, 65.5, 54.6; Anal. Calcd for $\mathrm{C}_{39} \mathrm{H}_{32} \mathrm{~N}_{2} \mathrm{O}_{5}$ : C, 76.96; H, 5.30; N, 4.60. Found: C, 76.85; H, 5.21; N, 4.71.
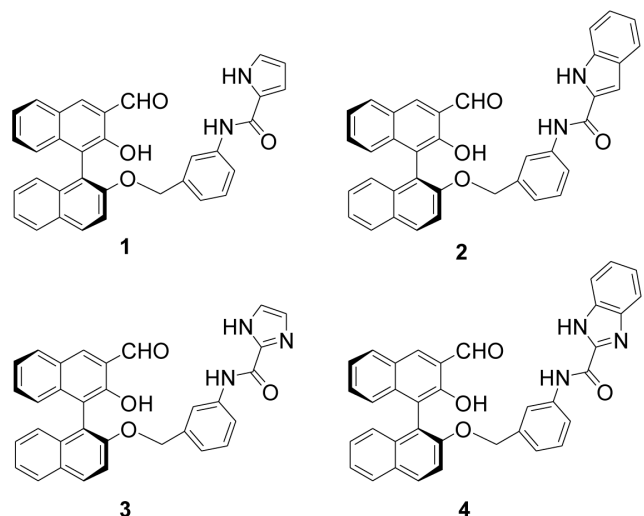

Scheme 1. pyrrole-2-carboxamide based binol receptors. 
2.4. (S)-3-Hydroxymethyl-2-Methoxymethoxy-2'-

(3-(1H-Imidazole-2-Carboxamido)-Benzyl)-1,10-Binaphthalene (8)

It was prepared similar to 6, but with imidazole-2-carboxylic acid. Isolated yield: $76 \%\left(\mathrm{mp} 70^{\circ} \mathrm{C}\right) .{ }^{1} \mathrm{H} \mathrm{NMR}$ $\left(\mathrm{CDCl}_{3}, 250 \mathrm{MHz}\right): \delta(\mathrm{ppm})=12.55(\mathrm{br} \mathrm{s}, 1 \mathrm{H}), 9.34(\mathrm{~s}, 1 \mathrm{H}), 8.38(\mathrm{~s}, 1 \mathrm{H}), 8.07$ - $7.85(\mathrm{~m}, 5 \mathrm{H}), 7.47$ - $7.15(\mathrm{~m}$, 9H), 7.09 (s, 1H), $6.97(\mathrm{~d}, 1 \mathrm{H}), 5.55$ (br s, $1 \mathrm{H}), 5.23$ - $4.90(\mathrm{~m}, 4 \mathrm{H}), 4.62(\mathrm{~s}, 2 \mathrm{H}), 2.99(\mathrm{~s}, 3 \mathrm{H}) ;{ }^{13} \mathrm{C}$ NMR $\left(\mathrm{CDCl}_{3}\right.$, $63 \mathrm{MHz}): \delta(\mathrm{ppm})=163.0,156.6,154.0,152.8,141.8,138.4,137.4,134.0,134.1,133.7,131.9,130.3,129.3$, 129.0, 128.6, 128.1, 126.9, 126.3, 125.7, 125.5, 125.1, 120.3, 118.7, 115.3, 99.3, 70.4, 61.5, 56.8. Anal. Calcd for $\mathrm{C}_{34} \mathrm{H}_{29} \mathrm{~N}_{3} \mathrm{O}_{5}$ : C, 72.97; H, 5.22; N, 7.51. Found: C, 72.81; H, 5.36; N, 7.43.

\section{5. (S)-3-Hydroxymethyl-2-Methoxymethoxy-2'-}

(3-(1H-Benzo[d]Imidazole-2-Carboxamido)-Benzyl)-1,10-Binaphthalene (9)

It was prepared similar to 6, but with benzimidazole-2-carboxylic acid. Isolated yield: $81 \%\left(\mathrm{mp} 246{ }^{\circ} \mathrm{C}\right) .{ }^{1} \mathrm{H}$ NMR (CDCl, $250 \mathrm{MHz}): \delta(\mathrm{ppm})=12.01(\mathrm{br} \mathrm{s}, 1 \mathrm{H}), 9.15(\mathrm{~s}, 1 \mathrm{H}), 8.52(\mathrm{~s}, 1 \mathrm{H}), 8.12-7.80(\mathrm{~m}, 4 \mathrm{H}), 7.58$ - 7.11 (m, 13H), $6.73(\mathrm{~d}, 1 \mathrm{H}), 5.10-4.87(\mathrm{~m}, 3 \mathrm{H}), 4.72-4.55(\mathrm{~m}, 4 \mathrm{H}), 3.42(\mathrm{~s}, 3 \mathrm{H}) ;{ }^{13} \mathrm{C} \mathrm{NMR}\left(\mathrm{CDCl}_{3}, 63 \mathrm{MHz}\right): \delta$ $(\mathrm{ppm})=161.3,158.3,149.8,145.5,141.7,138.9,138.5,136.1,132.1,129.8,129.5,129.0,128.5,128.0,127.9$, 120.4, 126.8, 125.7, 124.1, 123.6, 123.3, 120.5, 120.1, 119.5, 115.6, 115.3, 98.6, 74.8, 66.0, 58.4. Anal. Calcd for $\mathrm{C}_{38} \mathrm{H}_{31} \mathrm{~N}_{3} \mathrm{O}_{5}$ : C, 74.86; H, 5.13; N, 6.89. Found: C, 74.97; H, 5.01; N, 6.78.

\section{6. (S)-2-Methoxymethoxy-2'-(3-(1H-Pyrrole-2-}

Carboxamido)-Benzyl)-1,10-Binaphthyl-3-Carboxaldehyde (10)

A mixture of 6 ( $2.0 \mathrm{~g}, 3.6 \mathrm{mmol})$ and pyridinium chlorochromate (PCC) (1.5 g, $7.2 \mathrm{mmol})$ was dissolved in methylene chloride and stirred for $5 \mathrm{~h}$. The reaction mixture was filtered, and after evaporation and column chromatography with EA and hexane 1:2 mixture provided compound 10. Isolated yield: $79 \%\left(\mathrm{mp} 185^{\circ} \mathrm{C}\right) .{ }^{1} \mathrm{H}$ NMR $\left(\mathrm{CDCl}_{3}, 250 \mathrm{MHz}\right): \delta(\mathrm{ppm})=10.54(\mathrm{~s}, 1 \mathrm{H}) 10.17(\mathrm{br} \mathrm{s}, 1 \mathrm{H}), 8.46(\mathrm{~s}, 1 \mathrm{H}), 8.89$ - $7.74(\mathrm{~m}, 4 \mathrm{H}), 7.37$ - $7.01(\mathrm{~m}$, $10 \mathrm{H}), 6.83-6.72(\mathrm{~m}, 3 \mathrm{H}), 6.18(\mathrm{~s}, 1 \mathrm{H}), 5.01(\mathrm{~s}, 2 \mathrm{H}), 4.68(\mathrm{q}, 2 \mathrm{H}), 2.78(\mathrm{~s}, 3 \mathrm{H}) ;{ }^{13} \mathrm{C}$ NMR $\left(\mathrm{CDCl}_{3}, 63 \mathrm{MHz}\right): \delta$ $(\mathrm{ppm})=194.1,159.6,158.5,142.4,137.4,135.7,134.5,132.7,132.3,129.9,129.4,128.7,128.1,127.8,127.1$, 126.8, 125.7, 125.0, 124.6, 120.3, 120.1, 114.5, 112.6, 97.3, 73.5, 56.1. Anal. Calcd for $\mathrm{C}_{35} \mathrm{H}_{28} \mathrm{~N}_{2} \mathrm{O}_{5}$ : C, 75.52; $\mathrm{H}$, 5.07; N, 5.03. Found: C, 75.43; H, 5.15; N, 5.12.

\section{7. (S)-2-Methoxymethoxy-2'-(3-(1H-Indole-2-}

Carboxamido)-Benzyl)-1,10-Binaphthyl-3-Carboxaldehyde (11)

Same procedures as that of 10. Isolated yield: $82 \%\left(\mathrm{mp} \mathrm{201}{ }^{\circ} \mathrm{C}\right) .{ }^{1} \mathrm{H}$ NMR $\left(\mathrm{CDCl}_{3}, 250 \mathrm{MHz}\right): \delta(\mathrm{ppm})=10.59(\mathrm{~s}$, 1H), 10.33 (br s, 1H), 8.53 (s, 1H), $8.11-7.63(\mathrm{~m}, 6 \mathrm{H}), 7.47$ - 7.10 (m, 13H), 6.87 (d, 1H), 5.14 (q, 2H), 4.77 (q, 2H), 2.95 (s, 3H); ${ }^{13} \mathrm{C}$ NMR $\left(\mathrm{CDCl}_{3}, 63 \mathrm{MHz}\right): \delta(\mathrm{ppm})=192.5,159.7,158.5,152.8,145.2,144.1,139.5,138.6$, 135.9, 134.6, 134.1, 132.5, 131.2, 129.8, 128.9, 128.6, 126.5, 125.0, 124.5, 122.2, 121.6, 120.5, 120.1, 119.6, 119.2, 114.4, 108.0, 96.3, 71.2, 55.3. Anal. Calcd for $\mathrm{C}_{39} \mathrm{H}_{30} \mathrm{~N}_{2} \mathrm{O}_{5}$ : C, 77.21; H, 4.98; N, 4.62. Found: C, 77.14; H, 5.08; N, 4.69.

\section{8. (S)-2-Methoxymethoxy-2'-(3-(1H-Imidazole-2-}

Carboxamido)-Benzyl)-1,10-Binaphthyl-3-Carboxaldehyde (12)

Same procedures as that of 10. Isolated yield: $74 \%\left(\mathrm{mp} 185^{\circ} \mathrm{C}\right) .{ }^{1} \mathrm{H}$ NMR $\left(\mathrm{CDCl}_{3}, 250 \mathrm{MHz}\right): \delta(\mathrm{ppm})=10.60(\mathrm{~s}$, 1H), 10.45 (br s, 1H), 8.79 (s, 1H), $8.01-7.84(\mathrm{~m}, 4 \mathrm{H}), 7.35$ - $7.16(\mathrm{~m}, 9 \mathrm{H}), 6.73$ - $6.58(\mathrm{~m}, 3 \mathrm{H}), 6.35(\mathrm{~s}, 1 \mathrm{H})$, 5.13 (s, 2H), 4.75 (q, 2H), $3.02(\mathrm{~s}, 3 \mathrm{H}) ;{ }^{13} \mathrm{C}$ NMR $\left(\mathrm{CDCl}_{3}, 63 \mathrm{MHz}\right): \delta(\mathrm{ppm})=195.4,160.7,159.4,142.8$, 139.9, 136.7, 135.1, 132.8, 132.2, 129.8, 129.1, 128.6, 128.2, 127.9, 127.3, 126.4, 125.2, 125.3, 124.9, 121.4, 120.5, 115.7, 112.9, 97.7, 74.1, 57.2. Anal. Calcd for $\mathrm{C}_{34} \mathrm{H}_{27} \mathrm{~N}_{3} \mathrm{O}_{5}$ : C, 73.24; H, 4.88; N, 7.54. Found: C, 73.31; H, 5.01; N, 7.44.

\section{9. (S)-2-Methoxymethoxy-2'-(3-(1H-Benzo[d]}

Imidazole-Carboxamido)-Benzyl)-1,10-Binaphthyl-3-Carboxaldehyde (13)

Same procedures as that of 10. Isolated yield: $82 \%\left(\mathrm{mp} 168^{\circ} \mathrm{C}\right) ;{ }^{1} \mathrm{H}$ NMR $\left(\mathrm{CDCl}_{3}, 250 \mathrm{MHz}\right): \delta(\mathrm{ppm})=12.14$ 
(br s, 1H), 10.60 (s, 1H), 9.4 (s, 1H), 8.61 (s, 1H), 8.01 - 7.90 (m, 4H), 7.65 - 7.19 (m, 13H), 6.91 (d, 1H), 5.16 (q, 2H), 4.76 (q, 2H), 2.96 (s, 3H); ${ }^{13} \mathrm{C} \mathrm{NMR}\left(\mathrm{CDCl}_{3}, 63 \mathrm{MHz}\right): \delta(\mathrm{ppm})=194.3,160.8,159.0,158.1,152.8$, 145.6, 144.0, 138.7, 136.9, 135.7, 133.5, 131.9, 130.0, 129.9, 129.6, 128.8, 128.4, 127.6, 126.8, 124.3, 123.6, 123.1, 122.5, 121.1, 120.6, 118.9, 116.1, 115.9, 97.5, 73.5, 57.6. Anal. Calcd for $\mathrm{C}_{38} \mathrm{H}_{29} \mathrm{~N}_{3} \mathrm{O}_{5}$ : C, 75.11; $\mathrm{H}, 4.81$; N, 6.92. Found: C, 75.01; H, 4.73; N, 7.02.

\subsection{0. (S)-2-Hydroxy-2'-(3-(1H-Pyrrole-2-Carboxamido) -Benzyl)-1,10-Binaphthyl-3-Carboxaldehyde (1)}

To an ethanolic solution of $\mathbf{1 0}$ a few drops of conc. hydrochloric acid was added and refluxed for $30 \mathrm{~min}$. The solvent was evaporated and extracted with ethyl acetate to afford the desired receptor $\mathbf{1}$. Isolated yield: $98 \%$ (mp $\left.240^{\circ} \mathrm{C}\right) .{ }^{1} \mathrm{H} \mathrm{NMR}\left(\mathrm{CDCl}_{3}, 250 \mathrm{MHz}\right): \delta(\mathrm{ppm})=10.50$ (s, 1H), 10.18 (s, 1H), 9.45 (br s, $\left.1 \mathrm{H}\right), 8.30(\mathrm{~s}, 1 \mathrm{H}), 7.99-$ 7.87 (m, 3H), 7.48 - $7.16(\mathrm{~m}, 10 \mathrm{H}), 7.00-6.71(\mathrm{~m}, 4 \mathrm{H}), 6.35$ (s, $1 \mathrm{H}), 5.12(\mathrm{~s}, 2 \mathrm{H}) ;{ }^{13} \mathrm{C}$ NMR $\left(\mathrm{CDCl}_{3}, 63 \mathrm{MHz}\right)$ : $\delta(\mathrm{ppm})=196.9,158.8,154.0,153.4,138.3,137.9,130.3,130.1,129.7,128.9,128.2,127.5,126.7,125.5,124.8$, 124.2, 124.0, 122.5, 122.4, 122.1, 119.2, 115.6, 110.1, 109.5, 70.8; HRMS (FAB) calcd for $\mathrm{C}_{33} \mathrm{H}_{24} \mathrm{~N}_{2} \mathrm{O}_{4}$ : 512.1736, found: 512.1731 .

\subsection{1. (S)-2-Hydroxy-2'-(3-(1H-Indole-2-Carboxamido) -Benzyl)-1,10-Binaphthyl-3-Carboxaldehyde (2)}

It was prepared similar to receptor 1. Isolated yield: $98 \%\left(\mathrm{mp} 130^{\circ} \mathrm{C}\right) .{ }^{1} \mathrm{H}$ NMR $\left(\mathrm{CDCl}_{3}, 250 \mathrm{MHz}\right): \delta(\mathrm{ppm})=$ 10.55 (s, 1H), $10.10(\mathrm{~s}, 1 \mathrm{H}), 9.83(\mathrm{~s}, 1 \mathrm{H}), 8.18(1 \mathrm{H}, \mathrm{s}), 7.94$ - $7.73(\mathrm{~m}, 4 \mathrm{H}), 7.46$ - $7.15(\mathrm{~m}, 15 \mathrm{H}), 6.98(\mathrm{~d}, 1 \mathrm{H})$, 5.09 (s, 2H); ${ }^{13} \mathrm{C}$ NMR $\left(\mathrm{CDCl}_{3}, 63 \mathrm{MHz}\right): \delta(\mathrm{ppm})=196.9,159.7,154.0,153.4,138.3,137.9,136.9,130.5$, 130.3, 130.1, 129.7, 129.5, 128.9, 128.2, 127.5, 126.7, 125.4, 124.9, 124.8, 124.2, 122.0, 120.8, 115.4, 112.2, 103.1, 70.7; HRMS (FAB) calcd for $\mathrm{C}_{37} \mathrm{H}_{26} \mathrm{~N}_{2} \mathrm{O}_{4}$ : 562.1893, found: 562.1899.

\subsection{2. (S)-2-Hydroxy-2'-(3-(1H-Imidazole-2- Carboxamido)-Benzyl)-1,10-Binaphthyl-3-Carboxaldehyde (3)}

It was prepared similar to receptor 1 . Isolated yield: $75 \%\left(\mathrm{mp} 110^{\circ} \mathrm{C}\right) ;{ }^{1} \mathrm{H} \mathrm{NMR}\left(\mathrm{CDCl}_{3}, 250 \mathrm{MHz}\right): \delta 12.37$ (br s, $1 \mathrm{H}), 10.51(\mathrm{~s}, 1 \mathrm{H}), 10.12(\mathrm{~s}, 1 \mathrm{H}), 9.14(\mathrm{~s}, 1 \mathrm{H}), 8.28(\mathrm{~s}, 1 \mathrm{H}), 7.97-7.86(\mathrm{~m}, 3 \mathrm{H}), 7.63(\mathrm{~d}, 1 \mathrm{H}), 7.45$ - $7.11(\mathrm{~m}$, 11H), $6.83(\mathrm{~d}, 1 \mathrm{H}), 5.09$ (s, 2H); ${ }^{13} \mathrm{C} \mathrm{NMR}\left(\mathrm{CDCl}_{3}, 63 \mathrm{MHz}\right): \delta$ 196.9, 156.8, 154.0, 153.4, 138.4, 138.0, 137.1, 133.7, 130.3, 130.1, 129.8, 129.5, 128.2, 127.5, 126.7, 125.3, 125.0, 124.3, 124.0, 122.0, 118.7, 118.6, 115.7, 70.8; HRMS (FAB) calcd for $\mathrm{C}_{32} \mathrm{H}_{23} \mathrm{~N}_{3} \mathrm{O}_{4}$ : 513.1689, found: 513.1683 .

\subsection{3. (S)-2-Hydroxy-2'-(3-(1H-Benzo[d]Imidazole- \\ 2-Carboxamido)-Benzyl)-1,10-Binaphthyl-3-Carboxaldehyde (4)}

It was prepared similar to receptor 1 . Isolated yield: $98 \%\left(\mathrm{mp} 145^{\circ} \mathrm{C}\right) .{ }^{1} \mathrm{H}$ NMR $\left(\mathrm{CDCl}_{3}, 250 \mathrm{MHz}\right): \delta(\mathrm{ppm})=$ 12.31 (br s, $1 \mathrm{H}), 10.52(\mathrm{~s}, 1 \mathrm{H}), 10.16(\mathrm{~s}, 1 \mathrm{H}), 9.46(\mathrm{~s}, 1 \mathrm{H}), 8.51(\mathrm{~s}, 1 \mathrm{H}), 8.19-7.88(\mathrm{~m}, 4 \mathrm{H}), 7.71$ - $7.22(\mathrm{~m}$, 13H), $6.96(\mathrm{~d}, 1 \mathrm{H}), 5.19(\mathrm{~s}, 2 \mathrm{H}) ;{ }^{13} \mathrm{C} \mathrm{NMR}\left(\mathrm{CDCl}_{3}, 63 \mathrm{MHz}\right): \delta(\mathrm{ppm})=194.7,161.6,159.8,158.6,151.5$, 147.32, 146.1, 140.5, 138.9, 138.6, 136.9, 136.2, 132.7, 131.9, 129.9, 129.7, 128.7, 128.0, 126.6, 124.8, 123.7, 123.1, 122.8, 120.1, 116.5, 116.1, 72.6; HRMS (FAB) calcd for $\mathrm{C}_{36} \mathrm{H}_{25} \mathrm{~N}_{3} \mathrm{O}_{4}$ : 563.1845, found: 563.1840.

\section{Results and Discussion}

\section{Synthesis of the Receptors 1 - 4}

The synthesis of receptors $\mathbf{1}$ - $\mathbf{4}$ were previously reported by our group [24] which is described in Scheme 2 . The receptors were prepared from (S)-3-hydroxymethyl-2-methoxymethoxy-2'-(3-aminobenzyloxy)-1,1'-binaphthol (5) [20] [21] in dimethylformamide (DMF) and N-methyl morpholine (NMP) using the appropriate carboxylic acids. Subsequent oxidation and hydrolysis under the acidic conditions gave the final products. The synthesized compounds were confirmed by spectroscopic and analytical data which are in good agreement with the presented structures. All the receptors are freely soluble in solvents such as DMSO, $\mathrm{CHCl}_{3}$, benzene etc. (Scheme 2).

Stereoselective recognition of amino acids with receptor $\mathbf{1}$ was studied by ${ }^{1} \mathrm{H}$ NMR spectroscopy (Figure 1). Addition of $\left[\mathrm{Bu}_{4} \mathrm{~N}\right][\mathrm{L}-\mathrm{PheAla}]$ and $\left[\mathrm{Bu}_{4} \mathrm{~N}\right][\mathrm{D}-\mathrm{PheAla}]$ to $\mathbf{1}$ in DMSO- $d_{6}$ results in the formation of the corres- 

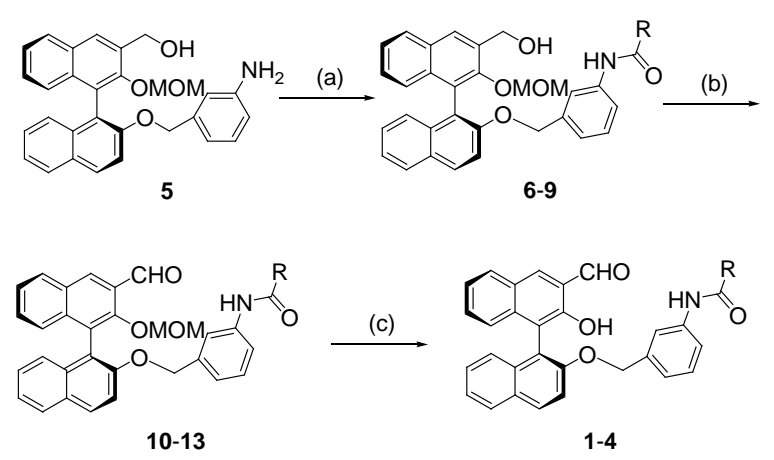

6,10 \& $1: R=2$-pyrrole $\quad 8,12 \& 3: R=2$-imidazole

$7,11 \& 2: R=2$-indole $\quad 9,13 \& 4: R=2$-benzimidazole

Scheme 2. Reagents and conditions: (a) PyBOP, DMF, NMP, R-COOH, rt, 15 h; (b) PCC, $\mathrm{CH}_{2} \mathrm{Cl}_{2}$, rt, 5 h; (c) $\mathrm{HCl}, \mathrm{EtOH}$, reflux, $0.5 \mathrm{~h}$.

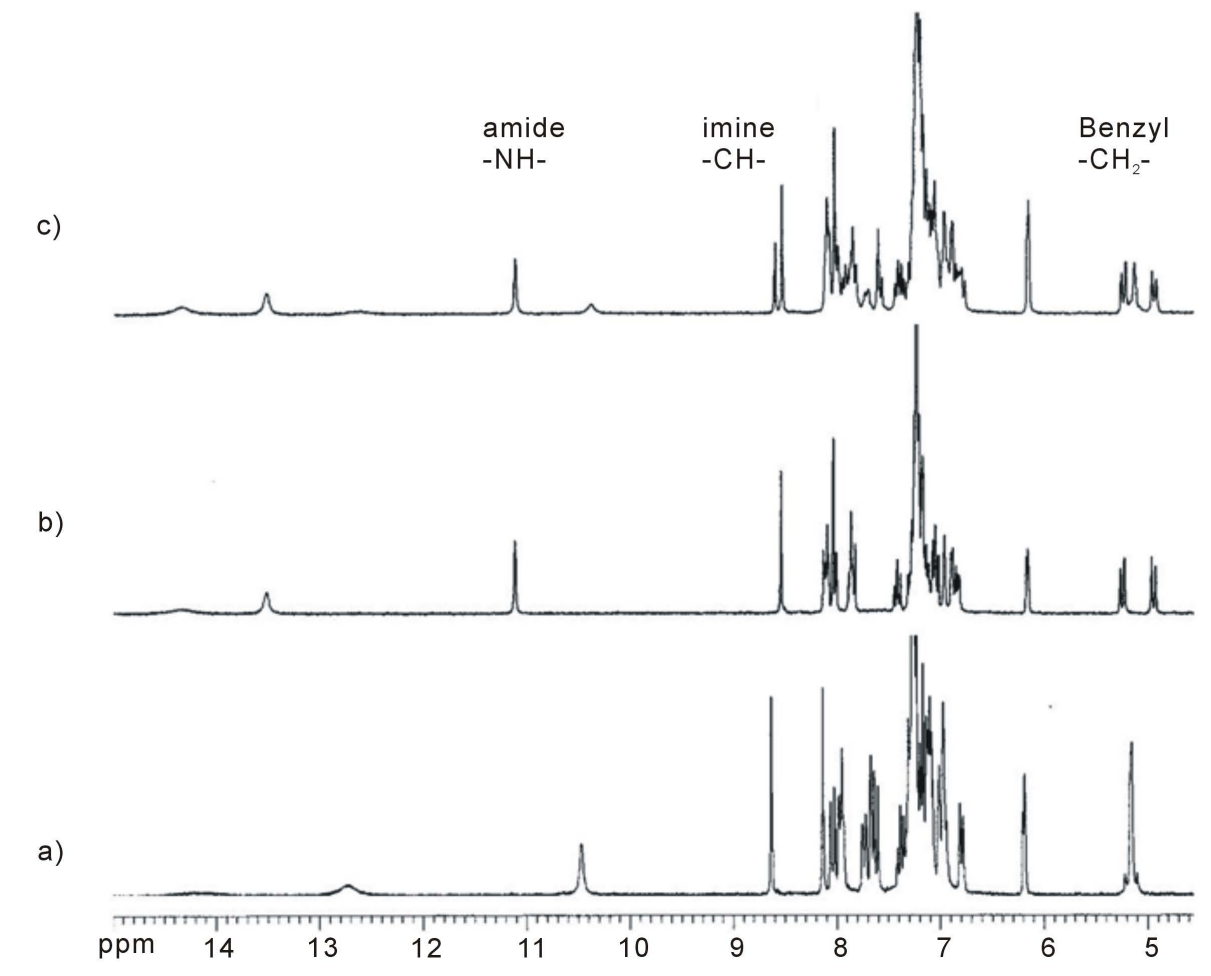

Figure 1. Partial ${ }^{1} \mathrm{H}$ NMR spectra indicating stereoselective imine formation of $\mathbf{1}$ with phenylalanine in DMSO [D $\mathrm{D}_{6}$. a) $\mathbf{1}+2\left[\mathrm{Bu}_{4} \mathrm{~N}\right][\mathrm{L}-\mathrm{PheAla}]$; b) $\mathbf{1}+2\left[\mathrm{Bu}_{4} \mathrm{~N}\right][\mathrm{D}-\mathrm{PheAla}]$; c) $\mathbf{1}+\mathbf{2}\left[\mathrm{Bu}_{4} \mathrm{~N}\right]$ [DL-PheAla].

ponding imines within $10 \mathrm{~min}$. Figures $\mathbf{1}(\mathrm{a})$ and (b) show the partial ${ }^{1} \mathrm{H}$ NMR spectra for $\mathbf{1}-\mathrm{L}-\mathrm{PheAla}$ and 1-D-PheAla, respectively. The signals of the amide $\mathrm{NH}$, imine $\mathrm{CH}$ and benzylic $\mathrm{CH}_{2}$ protons for $\mathbf{1}-\mathrm{L}-\mathrm{PheAla}$ and $1-D$-PheAla are all well resolved. Figure 1 (c) shows the partial ${ }^{1} \mathrm{H}$ NMR spectrum for the mixture of 1-L-PheAla and 1-D-PheAla formed by addition of two equivalents of racemic alanine to $\mathbf{1}$. Integration of the signals due to $\mathbf{1}-$ L-PheAla and 1-D-PheAla in Figure 1 (c) determines that the ratio of $\mathbf{1}-\mathrm{D}-\mathrm{PheAla} / \mathbf{1}-$ L-PheAla is 1.74:1. This indicates the imine formation constant for $\mathbf{1}-\mathrm{d}$-Ala is larger than that for $\mathbf{1}-\mathrm{l}$-Ala by a factor of about $1.74^{2}: 1$ or 3.03:1. Even if $1-\mathrm{L}-\mathrm{PheAla}$ is formed first by addition of one equivalent of [Bu $\mathrm{Bu}_{4} \mathrm{~N}$ ] [L-Ala], the above equilibrium ratio is obtained within 10 min upon addition of one equivalent of [Bu $\left.\mathrm{Bu}_{4} \mathrm{~N}\right][\mathrm{D}-\mathrm{Ala}]$ 
to the mixture. In this experiment, the epimerization of $\mathbf{1}-\mathrm{L}-\mathrm{PheAla}$ into $\mathbf{1}-\mathrm{D}-\mathrm{PheAla}$ is negligible, since the

${ }^{1} \mathrm{H}$ NMR spectra in Figures $1(\mathrm{a})$ and (b) do not change for a reasonable period of time.

Partial ${ }^{1} \mathrm{H}$ NMR spectra in Figure 2(a) demonstrates the CC of 1-L-PheAla (the imine formed between $\mathbf{1}$ and L-phenylalanine) to 1-D-PheAla in the presence of triethylamine in DMSO- $d_{6}$ as a representative. The imine $\mathrm{CH}$ signals are conveniently monitored as it is free from other signals. Therefore, the singlet peak at $8.69 \mathrm{ppm}$ assigned to the imine $\mathrm{CH}$ proton of 1-L-PheAla decreases and the singlet peak at $8.48 \mathrm{ppm}$ ascribed to the imine $\mathrm{CH}$ of 1-D-PheAla, increases concomitantly. The CC reaches the equilibrium at $48 \mathrm{~h}$ where the stereoselectivity, which is defined by the ratio of (1-D-PheAla)/(1-L-PheAla) is measured by the integration of the ${ }^{1} \mathrm{H}$ NMR signals.

Table 1 compares the stereoselectivities of the pyrrole based receptors $\mathbf{1}$ - $\mathbf{4}$ for six different amino acids, i.e. Alanine, Glutamine, Histidine, Phenylalanine, Serine and Tyrosine assessed by the same procedures. The results from the table indicates that the receptors $\mathbf{1}$ and $\mathbf{3}$ show higher conversion efficiency to amino acids than receptors $\mathbf{2}$ and $\mathbf{4}$. The lower stereoselectivities of $\mathbf{2}$ and $\mathbf{4}$ compared to $\mathbf{1}$ and $\mathbf{3}$ may be presumably due to the lower hydrogen bond donor capability and steric hindrance of the additional benzene moiety [25]. The stereoselectivity and chirality conversion, depends on the degree of the difference of steric energies around imine bonds between 1-L-aa and 1-D-aa (Scheme 3). This will be maximized in the condition that the whole imine complex is rigid by hydrogen bonds (resonance assisted hydrogen bond between imine nitrogen and phenolic -OH, and the hydrogen bond between heterocyclic - $\mathrm{NH}$ and carboxylic acid - $\mathrm{COOH}$ ).

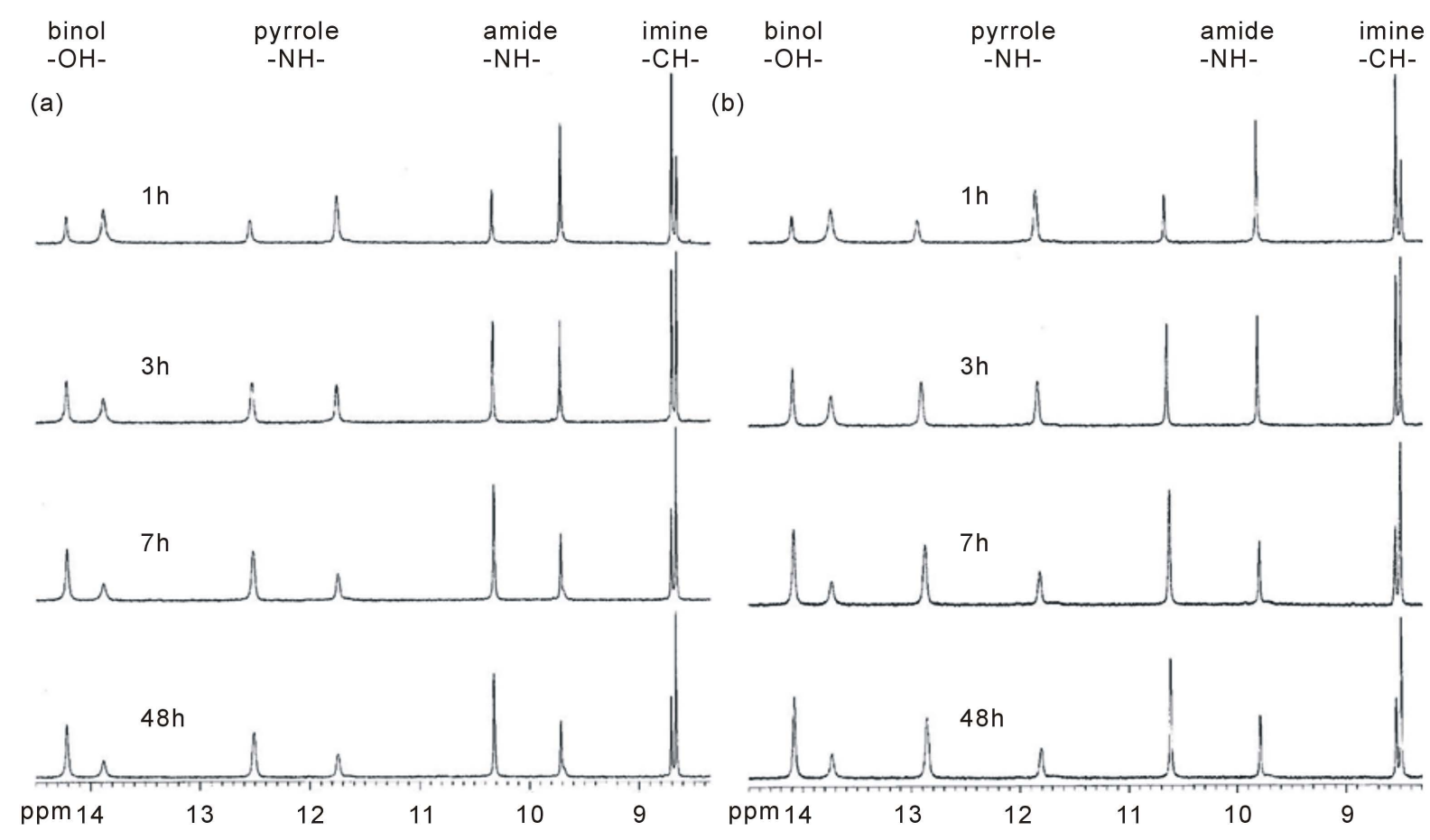

Figure 2. Partial ${ }^{1} \mathrm{H}$ NMR spectra indicating the conversion of $1-\mathrm{L}$-aa into $1-\mathrm{D}$-aa. The peaks corresponding to $1-\mathrm{L}$-aa decrease while those corresponding to $1-\mathrm{D}$-aa increase (from top to bottom). (a) conversion of L-PheAla into D-PheAla; (b) conversion of L-Ser into D-Ser.

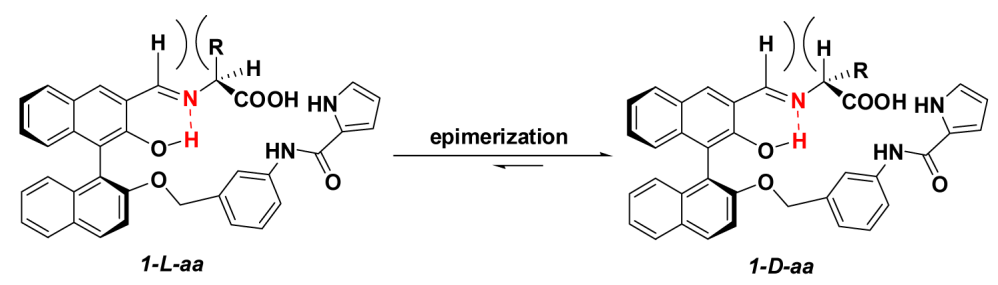

Scheme 3. Difference of steric energies around imine bonds between 1-L-aa and 1-D-aa. 
Table 1. L to D conversion efficiency of the receptors for amino acid.

\begin{tabular}{|c|c|c|c|c|}
\hline \multirow[b]{2}{*}{ Amino acid } & \multicolumn{4}{|c|}{ Receptors } \\
\hline & 1 & 2 & 3 & 4 \\
\hline Alanine & 2.45 & 1.95 & 2.25 & 1.41 \\
\hline Glutamine & 2.77 & 2.36 & 2.86 & 1.13 \\
\hline Histidine & 2.67 & 2.18 & 2.42 & 1.25 \\
\hline Phenylalanine & 2.93 & 2.22 & 2.65 & 1.16 \\
\hline Serine & 2.35 & 2.17 & 2.12 & 1.47 \\
\hline Tyrosine & 2.77 & 2.24 & 2.81 & 1.37 \\
\hline
\end{tabular}

The Diastereomeric ratio, (D-amino acid bound imine)/(L-amino acid imine), was determined by ${ }^{1} \mathrm{H}-\mathrm{NMR}$ in DMSO- $\mathrm{d}_{6}$ at equilibirium.

\section{Conclusion}

In summary, four pyrrole carboxamide based receptors were explored as Chirality conversion reagents for six underivatized amino acids. Though these receptors were not efficient as that of the Binol based receptors reported earlier, they are the first receptors based on the heterocyclic moiety which can be utilized as Chirality Conversion Reagents. Receptors $\mathbf{1}$ and $\mathbf{3}$ show higher conversion efficiency than the receptors $\mathbf{2}$ and $\mathbf{4}$.

\section{Acknowledgements}

This work is supported by the Fast Track Programme for the young Scientists of the DST (No. SR/FT/CS95/2010).

\section{References}

[1] Collins, A.N., Sheldrake, G.N. and Crosby, J. (1997) Chirality in Industry. Wiley and Sons, Chichester.

[2] Kazlauskas, R.J. (2006) Engineering a Multipurpose Catalyst. Nature Chemical Biology, 2, 514-515. http://dx.doi.org/10.1038/nchembio1006-514

[3] Nandanwar, H.S., Gurinder, S., Hoondal, G.S. and Vohra, R.M. (2005) Enzymatic Production of D-Amino Acids. In: Barredo, J.L., Ed., Microbial Enzymes and Biotransformations, 91-104.

[4] Maruoka, K. and Ooi, T. (2003) Enantioselective Amino Acid Synthesis by Chiral Phase-Transfer Catalysis. Chemical Reviews, 103, 3013-3028. http://dx.doi.org/10.1021/cr020020e

[5] Kemperman, G.J., Zhu, J., Klunder, A.J.H. and Zwanenburg, B. (2000) Clathration-Induced Asymmetric Transformation of Cefadroxil. Organic Letters, 2, 2829-2831. http://dx.doi.org/10.1021/ol006261v

[6] Vedha-Peters, K., Gunawardana, M., Rozzell, J.D. and Novick, S.J. (2006) Creation of a Broad-Range and Highly Stereoselective d-Amino Acid Dehydrogenase for the One-Step Synthesis of d-Amino Acids. Journal of American Chemical Society, 128, 10923-10929. http://dx.doi.org/10.1021/ja0603960

[7] Kimura, T., Vassilev, V.P., Shen, G.-J. and Wong, C.H. (1997) Enzymatic Synthesis of $\beta$-Hydroxy- $\alpha$-Amino Acids Based on Recombinant d- and l-Threonine Aldolases. Journal of American Chemical Society, 119, 11734-11742. http://dx.doi.org/10.1021/ja9720422

[8] Turner, N.J. (2004) Enzyme Catalysed Deracemisation and Dynamic Kinetic Resolution Reactions. Current Opinion in Chemical Biology, 8, 114-119. http://dx.doi.org/10.1016/j.cbpa.2004.02.001

[9] Zhang, X.X., Bradshaw, J.S. and Izatt, R.M. (1997) Enantiomeric Recognition of Amine Compounds by Chiral Macrocyclic Receptors. Chemical Reviews, 97, 3313-3362. http://dx.doi.org/10.1021/cr960144p

[10] Breccia, P., Van Gool, M., Perez-Fernandez, R., Martin-Santamaria, S., Gago, F., Prados, P. and Mendoza, J. (2003) Guanidinium Receptors as Enantioselective Amino Acid Membrane Carriers. Journal of American Chemical Society, 125, 8270-8284. http://dx.doi.org/10.1021/ja026860s

[11] Oliva, A.I., Simon, L., Hernandez, J.V., Muniz, F.M., Lithgow, A., Jimenez, A. and Moran, J.R. (2002) Enantioselective Recognition of $\alpha$-Amino Acid Derivatives with a Cis-Tetrahydrobenzoxanthene Receptor. Journal of Chemical Society, Perkin Transactions, 2, 1050-1052. http://dx.doi.org/10.1039/b203054c

[12] Yang, Y., Kochoyan, M., Burgstaller, P., Westhof, E. andFamulok, M. (1996) Structural Basis of Ligand Discrimination by Two Related RNA Aptamers Resolved by NMR Spectroscopy. Science, 272, 1343-1347. http://dx.doi.org/10.1126/science.272.5266.1343

[13] Osawa, T., Shirasaka, K., Matsui, T., Yoshihara, S., Akiyama, T., Hishiya, T., Asanuma, H. and Komiyama, M. (2006) Importance of the Position of Vinyl Group on $\beta$-Cyclodextrin for the Effective Imprinting of Amino Acid Derivatives 
and Oligopeptides in Water. Macromolecules, 39, 2460-2466. http://dx.doi.org/10.1021/ma060064f

[14] Okuno, H., Kitano, T., Yakabe, H., Kishimoto, M., Deore, B.A., Siigi, H. and Nagaoka, T. (2002) Characterization of Overoxidized Polypyrrole Colloids Imprinted with l-Lactate and Their Application to Enantioseparation of Amino Acids. Analytical Chemistry, 74, 4184-4190. http://dx.doi.org/10.1021/ac0258220

[15] Reeve, T.B., Cros, J.P., Gennari, C., Piarulli, U. and Vries, J.G. (2006) A Practical Approach to the Resolution of Racemic N-Benzyl $\alpha$-Amino Acids by Liquid-Liquid Extraction with a Lipophilic Chiral Salen-Cobalt(III) Complex. Angewandte Chemie International Edition, 118, 2509-2513.

[16] Chin, J., Lee, S.S., Lee, K.J., Park, S. and Kim, D.H. (1999) A Metal Complex That Binds Alpha-Amino Acids with High and Predictable Stereospecificity. Nature, 401, 254-257. http://dx.doi.org/10.1038/45751

[17] Park, H., Kim, K.M., Lee, A., Ham, S., Nam, W. and Chin, J. (2007) Bioinspired Chemical Inversion of l-Amino Acids to d-Amino Acids. Journal of American Chemical Society, 129, 1518-1519. http://dx.doi.org/10.1021/ja067724g

[18] Tang, L., Ga, H., Kim, J., Choi, S., Nandhakumar, R. and Kim, K.M. (2008) Chirality Conversion and Enantioselective Extraction of Amino Acids by Imidazolium-Based Binol-Aldehyde. Tetrahedron Letters, 49, 6914-6916. http://dx.doi.org/10.1016/j.tetlet.2008.09.117

[19] Nandhakumar, R., Ryu, J., Park, H., Tang, L., Choi, S. and Kim, K.M. (2008) Effects of Ring Substituents on Enantioselective Recognition of Amino Alcohols and Acids in Uryl-Based Binol Receptors. Tetrahedron, 64, 7704-7708. http://dx.doi.org/10.1016/j.tet.2008.06.029

[20] Park, H., Nandhakumar, R., Hong, J., Ham, S., Chin, J. and Kim, K.M. (2008) Stereoconversion of Amino Acids and Peptides in Uryl-Pendant Binol Schiff Bases. Chemistry-A European Journal, 14, 9935-9942. http://dx.doi.org/10.1002/chem.200801036

[21] Park, H., Hong, J., Ham, S., Nandhakumar, R. and Kim, K.M. (2009) Chirality Conversion of Dipeptides in the Schiff Bases of Binol Aldehydes with Multiple Hydrogen Bond Donors. Bulletin-Korean Chemical Society, 30, 409-414. http://dx.doi.org/10.5012/bkcs.2009.30.2.409

[22] Meyer, C.D., Joiner, C.S. and Stoddart, J.F. (2007) Template-Directed Synthesis Employing Reversible Imine Bond Formation. Chemical Society Reviews, 36, 1705-1723. http://dx.doi.org/10.1039/b513441m

[23] Feuster, E.K. and Glass, T.E. (2003) Detection of Amines and Unprotected Amino Acids in Aqueous Conditions by Formation of Highly Fluorescent Iminium Ions. Journal of American Chemical Society, 125, 16174-16175. http://dx.doi.org/10.1021/ja036434m

[24] Nandhakumar, R., Soo, A.Y., Hong, J., Ham, S. and Kim, K.M. (2009) Enantioselective Recognition of 1,2-Aminoalcohols by the Binol Receptor Dangled with Pyrrole-2-Carboxamide and Its Analogues. Tetrahedron, 65, 666-671. http://dx.doi.org/10.1016/j.tet.2008.11.022

[25] Catalan, J., Elguero, J., Flammang, R. and Maquestiau, A. (1983) The Relative Basicities of Imidazole and Benzimidazole. Angewandte Chemie International Edition in English, 22, 323-324. http://dx.doi.org/10.1002/anie.198303231 